Section Editor

John J. Millichap, MD

Teaching NeuroImages:

\title{
Granulomatosis with polyangiitis causing Collet-Sicard syndrome and refractory headache
}

Nathaniel M. Schuster, MD

Stellios Karnezis, MD Lucas Restrepo, MD, $\mathrm{PhD}$

Correspondence to

Dr. Schuster:

nschuster@gmail.com

\section{Figure 1 Clinical examination before immunosuppression}
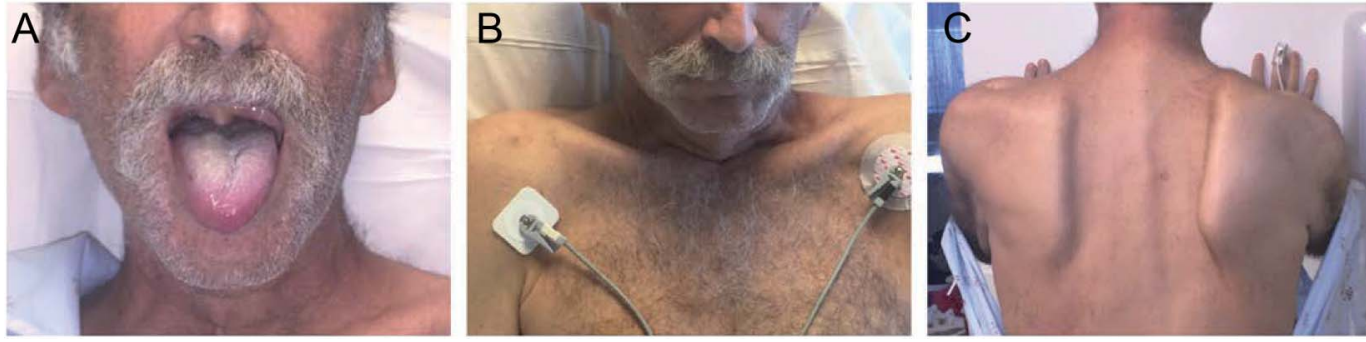

Examination revealed multiple cranial neuropathies as evidenced by palatal asymmetry $(\mathrm{A})$, right trapezius atrophy (B) with scapular winging $(C)$, and rightward tongue deviation (A).

A 52-year-old man presented for 4 months of progressive hypophonia and dysphagia with refractory headache and bilateral otitis media. Examination and MRI revealed abnormalities (figures 1 and 2). Serum proteinase 3 antibody level was 180 units (normal $<21$ units) and c-ANCA (antineutrophil cytoplasmic antibody) was 1:160, consistent with granulomatosis with polyangiitis $(\mathrm{GPA}$; previously known as Wegener granulomatosis). Lung nodule biopsy confirmed GPA.

Cranial neuropathies are a recognized complication of GPA. ${ }^{1,2}$ Collet-Sicard syndrome represents cranial nerve 9-12 palsies with sympathetic sparing. Collet-Sicard syndrome can be due to intracranial or extracranial pathology; differential diagnosis includes neoplasm (such as carotid

Figure 2 MRI brain retrostyloid parapharyngeal space heterogenously enhancing material
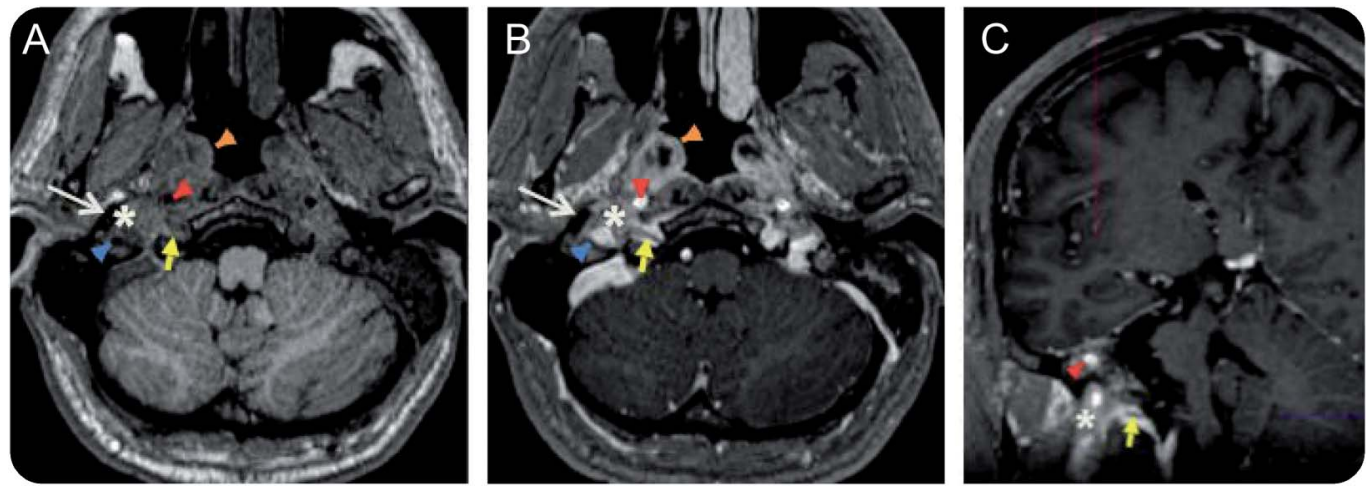

(A) Axial T1 precontrast; (B) axial T1 postcontrast; and (C) sagittal oblique T1 postcontrast abnormally enhancing material (asterisk) between internal carotid/carotid canal (red arrowhead) and jugular vein/jugular foramen (blue arrowhead) extending to styloid process (white arrow) and nasopharyngeal mucosa/torus tubarius (orange arrowhead). Hypoglossal nerve (yellow arrow) is obscured past the hypoglossal canal.

Download teaching slides: Neurology.org

From the Montefiore Headache Center (N.M.S.), Department of Neurology, Montefiore Medical Center, Albert Einstein College of Medicine, Bronx, NY; and Departments of Radiology (S.K.) and Neurology (N.M.S., L.R.), Ronald Reagan-UCLA Medical Center, Los Angeles, CA. Go to Neurology.org for full disclosures. Funding information and disclosures deemed relevant by the authors, if any, are provided at the end of the article. 
body paraganglioma), infection, and inflammatory disorders.

\section{AUTHOR CONTRIBUTIONS}

Nathaniel M. Schuster, MD, participated in design and conceptualization of the study, analysis and interpretation of the data, and drafting of the manuscript. Stellios Karnezis, MD, participated in analysis and interpretation of the data and drafting of the manuscript. Lucas Restrepo, $\mathrm{MD}, \mathrm{PhD}$, participated in design and conceptualization of the study, analysis and interpretation of the data, and revising the manuscript for intellectual content.

\section{STUDY FUNDING}

No targeted funding reported.

\section{DISCLOSURE}

The authors report no disclosures relevant to the manuscript. Go to Neurology.org for full disclosures.

\section{REFERENCES}

1. de Groot K, Schmidt DK, Arlt AC, Gross WL, ReinholdKeller E. Standardized neurologic evaluations of 128 patients with Wegener granulomatosis. Arch Neurol 2001; 58:1215-1221.

2. Zhang W, Zhou G, Shi Q, Zhang X, Zeng XF, Zhang FC. Clinical analysis of nervous system involvement in ANCAassociated systemic vasculitides. Clin Exp Rheumatol 2009; 27:S65-S69. 


\title{
Neurology
}

\author{
Teaching NeuroImages: Granulomatosis with polyangiitis causing Collet-Sicard \\ syndrome and refractory headache \\ Nathaniel M. Schuster, Stellios Karnezis and Lucas Restrepo \\ Neurology 2015;85; 179-e180 \\ DOI 10.1212/WNL.0000000000002192
}

This information is current as of December 7, 2015

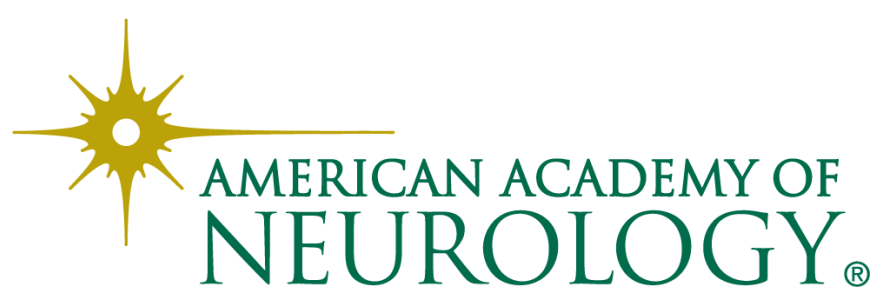




\section{Updated Information \& Services}

\section{Supplementary Material}

References

Citations

Subspecialty Collections

Permissions \& Licensing

\section{Reprints}

including high resolution figures, can be found at: http://n.neurology.org/content/85/23/e179.full

Supplementary material can be found at: http://n.neurology.org/content/suppl/2015/12/05/WNL.0000000000002 192.DC1

This article cites 2 articles, 0 of which you can access for free at: http://n.neurology.org/content/85/23/e179.full\#ref-list-1

This article has been cited by 1 HighWire-hosted articles: http://n.neurology.org/content/85/23/e179.full\#\#otherarticles

This article, along with others on similar topics, appears in the following collection(s):

\section{Autoimmune diseases}

http://n.neurology.org/cgi/collection/autoimmune_diseases

Clinical neurology examination

http://n.neurology.org/cgi/collection/clinical_neurology_examination

\section{MRI}

http://n.neurology.org/cgi/collection/mri

Secondary headache disorders

http://n.neurology.org/cgi/collection/secondary_headache_disorders Vasculitis

http://n.neurology.org/cgi/collection/vasculitis

Information about reproducing this article in parts (figures,tables) or in its entirety can be found online at:

http://www.neurology.org/about/about_the_journal\#permissions

Information about ordering reprints can be found online:

http://n.neurology.org/subscribers/advertise

Neurology ${ }^{\circledR}$ is the official journal of the American Academy of Neurology. Published continuously since 1951, it is now a weekly with 48 issues per year. Copyright () 2015 American Academy of Neurology. All rights reserved. Print ISSN: 0028-3878. Online ISSN: 1526-632X.

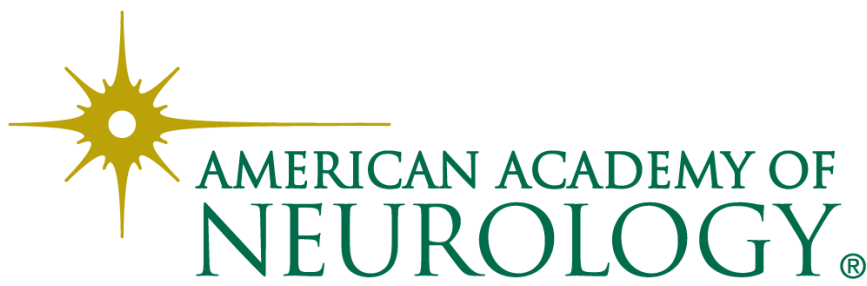

